\title{
Supervisi Pendidikan Untuk Mewujudkan Pendidikan Karakter
}

\author{
Oleh: Farhan febly \\ Jurusan Kimia \\ Universitas Negeri Padang \\ Padang, Indonesia \\ Farhan130299@gmail.com
}

\begin{abstract}
Hingga saat sekarang pendidikan karakter masih menjadi salah satu isu utama dalam pendidikan Indonesia. Dalam UU No. 20 Tahun 2003 tentang pendidikan nasiaonal pasal 3 menyatakan fungsi dari pendidikan nasional adalah mengembangkan kemampuan dan membentuk karakter serta peradaban bangsa yang bermartabat dalam rangka mencerdaskan kehidupan bangsa. Ada banyak faktor yang dapat membentuk karakter siswa. Kebijakan sekolah merupakan salah satu unsur yang dapat menghujudkan pendidikan berkarakter tersebut. Kebijakan sekolah tidak akan beerjalan baik tanpa seorang pendidik yang mampu untuk bersikap professional. Guru yang professional akan mampu untuk meningkatkan kualitas pembelajaran. Tidak hanya sampai di situ kepala sekolah juga berperan penting dalam menwujudkan pendidikan berkarakter tersebut. Karena kepala sekolah adalah pengelola terdepan yang memutuskan dapat atau tidaknya peserta didik berproses dan berinteraksi secara positif dalam proses belajar mengajar, dan juga memiliki peran yang dominan untuk mendorong upaya inovasi yang berasal dari dalam maupun dari luar sekolah. Supervisi pendidikan adalah pembinaan yang berupa bimbingan atau tuntunan kearah perbaikan situasi pendidikan pada umumnya dan peningkatan mutu mengajar dan belajar khususnya. Oleh sebab itu supervisi akan mewujudkan seluruh fungsi pengajaran termasuk pengajaran terhadap nilai nilai karakter atau norma norma dalam kehidupan.
\end{abstract}

Kata kunci: Pendidikan berkarakter

\section{Pendahuluan}

pendidikan karakter merupakan adalah secara umum fungsinya adalah untuk membentuk dan melatih kemampuan individu peserta didik secara terus menerus untuk menyempurnakan diri kea rah yang lebih baik. Pendidikan berkarakter berupa sistem pendidikan yang bertujuan untuk menanamkan nilai nilai karakter tertentu peserta didik yang di dalamnya terdapat komponen pengetahuan pengetahuan dan kesadaran serta tindakan untuk melakukan nilai nilai tersebut. Pendidikan karakter merupakan tujua nnasional bangsa Indonesia. Menurut (Citra, 2012) Dalam Undang-undang (UU) No.20, tahun 2003 tentang Sistem Pendidikan Nasional pasal 3 dinyatakan bahwa Pendidikan nasional berfungsi mengembangkan kemampuan dan membentuk watak serta peradaban bangsa yang bermartabat dalam rangka mencerdaskan kehidupan bangsa, bertujuan untuk berkembangnya potensi peserta didik agar menjadi manusia yang beriman dan bertaqwa kepada Tuhan Yang Maha Esa, berakhlak mulia, sehat, berilmu, cakap, kreatif, mandiri, dan menjadi warga Negara yang demokratis serta bertanggung jawab. Sehingga nanatinya mampu menjadi anak bangsa yang membanggakan. Sebab anak merupakan dambaan bagi setiap orang tua dan anak adalah bagian dari generasi sebagai salah satu dari sumber daya manusia yang merupakan potensi dan penerus cita-cita perjuangan bangsa.

Namun pada saat sekarang pendidikan berkarakter belum tampak di dalam ranah pendidikan di Indonesia. Saat sekarang begitu banyak prilaku dari peserta didik, siswa maupun mahasiswa yang melenceng dari norma norma atau nilai nilai kebaikan yang berlaku di masyarakat.hampir setiap tahunnya kita menemukan begitu banyak kasus tawuran antar siswa. Mereka juga melakukan perusakan-perusakan terhadap lingkungan masyarakat setempat. Dan masih banyak lagi bentuk kerusakan moral dari peserta didik di zaman milineal ini, seperti sex bebas, narkoba, 
minuman keras, pembulian terhadap junior di sekolah, geng motor di kalangan peserta didik dan lain sebagainya umumnya terjadi terhadap siswa SMP dan SMA.

Permasalahan yang banyak tersebut tidak bisa terlepas dari pendidikan yang mereka dapatkan dari sekolah. Padahal para siswa tersebut talah menjalani pendidikan formal (sekolah) semenjak kecil yakni saat berumur 6 tahun. Selama 6 tahun menjalani pendidikan di sekolah dasar para peserta didik seolah-olah tidak mendapatkan nilai moral dalam kehidupan. Terlepas dari keluarga dan masyarakat sekitar dari peserta didik idealnya sekolah merupakan salah satu tempat pembentuk karakter siswa . keberadaan guru sebagai person yang di gugu dan di tiru merupakan salah satu unsur penting dalam membentuk karakter para peserta didik. Sehingga buruknya karakter sisiwa tersebut tidak bisa disalahkan sepenuhnya terhadap siswa itu. Buruknya karakter siswa melambangkan hasil yang di dapatkan dari pendidikan yang diberikan seorang guru tidak benar. Seorang guru tentunya di awasi oleh kepala sekolah, sehingga buruknya pengawasan dari kepala sekolah member dampak negative terhadap kinerja guru yang berpengaruh terhadap karakter siswa.

Dari uraian di atas, permasalahan dalam tulisan ini adalah (1) Bagaimana pengawasan kepala sekolah dan proses pembelajaran di kelas oleh seorang guru berbengaruh terhadap karakter siswa. (2) Bagimana supervisi pendidikan berperan penting terhadap pembentukan karakter peserta didik. Tujuan penulisan ini adalah untuk mengetahui bagaimana supervisi pendidikan dalam mewujudkan pendidikan karakter.

\section{Pembahasan}

\section{a. Pelaksanaan Pendidikan Berkarakter}

Pelaksanaan pendidikan karakter dalam pembelajaran sangat diperlukan untuk membentuk karakter peserta didik dan menanamkan nilai-nilai maupun norma kehidupan. Menurut (Citra, 2012) (dikutip dari Tarmansyah 2012:15, 2012) Dalam pendidikan karakter yang diintegrasikan didalam mata pelajaran, ada hal-hal yang perlu diperhatikan seperti:

a. Kebijakan sekolah dan dukungan administrasi sekolah terhadap pendidikan karakter yang meliputi: Visi dan misi pendidikan karakter, sosialisasi, dokumen pendidikan karakter dll.

b. Kondisi lingkungan sekolah meliputi: sarana dan prasarana yang mendukung, lingkungan yang bersih, kantin kejujuran, ruang keagamaan dll.

c. Pengetahuan dan sikap guru yang meliputi: konsep pendidikan karakter, cara membuat perencanaan pembelajaran, perangkat pembelajaran, kurikulum, silabus, RPP, bahan ajar, penilaian, pelaksanaan pendidikan karakter terintegrasi dalam mata pelajaran dll.

d. Peningkatan kompetensi guru.

e. Dukungan masyarakat.

Dari penjelasan di atas bahwa kebijakan sekolah juga merupakan unsure penting dalam mewujudkan proses pembelajaran pembentukan karakter siswa. Dan juga kebijakan sekolah tidak bisa di lepaskan dari peran penting seorang kepala sekolah. Kepala sekolah merupakan pengelola terdepan yang memutuskan dapat atau tidaknya peserta didik berproses dan berinteraksi secara positif dalam proses belajar mengajar, dan juga memiliki peran yang dominan untuk mendorong upaya inovasi yang berasal dari dalam maupun dari luar sekolah. Sehingga dapat dikatakan bahwa kepala sekolah memiliki wewenang untuk mengawasi dan mengatur kinerja guru dalam proses belajar mengajar demi terwujudnya pendidikan yang bermutu dan berkualitas.

\section{b. Urgensi Kepala Sekolah Mewujudkan Pendidikan Berkarakter}

Menurut (Ekosiswoyo, 2007) Kepala Sekolah merupakan pemimpin pendidikan pada tingkat operasional yang berada di garis terdepan yang mengkoordin akan upaya meningkatkan kualitas pendidikan. Tentu saja Kepala Sekolah bukan satu-satunya determinan bagi efektif tidaknya suatu sekolah karena masih banyak faktor lain yang perlu diperhatikan. Namun, Kepala Sekolah memainkan peran kunci yang sangat menentukan. Jadi kualitas pendidikan yang berlansung di sekolah tersebut tidak terlepas dari kepala sekolah. Kepala sekolah juga merupakan unsur penting dalam meningkatkan kualitas pendidikan di sekolah tersebut. Karna bagaimana pun seorang pemimpin punya tanggung jawab terhadap apa yang di pimpinnya. Kemudian (Ekosiswoyo, 2007) (mengutip 
Lightfoot, 1983 dari penelitian Wohlstetter, Priscilla, 1997) Studi pendekatan sosiologi tentang efektivitas sekolah menunjukkan bahwa kepemimpinan Kepala Sekolah memainkan peranan yang sangat penting dan vital, kemudian Penelitian menyimpulkan bahwa perhatian Kepala Sekolah yang tinggi terhadap pembinaan mutu, perilakunya yang terpuji, dan sikap responsifnya dalam mena ngani persoalan yang timbul di sekolah secara signifikan menurunkan frekuensi perilaku tak terpuji pada siswa dan sebaliknya meningkatkan kehidupan sekolah.

(Ekosiswoyo, 2007) ( mengutip Gaustad, 1992) menemukan bahwa Kepala Sekolah terbukti menunjukkan peranan kunci dalammenegakkan disiplin sekolah melalui kemampuan-nya dalam mengelola sekolah, memberikan teladan kepada siswa dan guru, serta melakukan teknik-teknik "social reward"kepada siswa dan guru. Kepala sekolah juga teladan utama tidak hanya untuk siswa tetapi juga untuk guru sebagai pimpinan di sekolah tersebut. Karna wibawa dan sikap seorang pemimpin akan dilihat lansung oleh bawahannya. Sehingga dapat dikatakan kepala sekolah merupakan panutan dari setiap element yang ada di sekolah tersebut mulai dari guru, staf ahli hingga terhadap siswa. Prilaku yang buruk dari seorang kepala sekolah akan menjadi contoh terhadap peserta didik, begitu juga sebaliknya jika kepala sekolah bersikap baik maka akan menjadi panutan yang baik oleh siswa.

\section{c. Urgensi Guru Mewujudkan Pendidikan Berkarakter}

Guru juga memiliki peran penting dalam membentuk karakter siswa menurut (Wardani, 2010) menyatakan bahwa lingkungan sekolah, pendidikan diberikan kepada anak didik dalam waktu terbatas, sehingga terbatas pula waktu bagi para siswa untuk berkomunikasi dan berinteraksi dengan guru. Oleh sebab itu, guru harus berkonsentrasi memberi perhatian kepada kepribadian dan fisik anak didik secara terbatas pula. Di dalam lingkungan keluarga, anak sesungguhnya sudah dididik sejak dalam kandungan. Keluarga menjadi kiblat perjalanan dari dalam kandungan sampai tumbuh menjadi dewasa dan berlanjut di kemudian hari. Di lingkungan masyarakat, karakter dan wawasan serta tingkah laku seseorang akan mencerminkan karakter. Berada pada lingkungan macam apa sehingga anak didik itu otomatis melekat pada akar masyarakat sekitarnya. Integritas san kepribadian sang anak akan bisa dilihat dari akar sosial lingkungannya. Oleh sebab itu interaksi guru dan siswa harus dijaga dengan baik. Tidak hanya sampai di situ karena keluarga dan masyarakat memiliki pengaruh yang besar terhadap karakter siswa. Maka seorang guru juga harus bisa menjaga komunikasi dengan baik terhadap keluarga dan lingkungan masyarakat siswa.

\section{d. Tata Kelola Supervisi Pendidikan di Sekolah}

Menurut (Sabandi, 2013) menyatakan bahwa Seharusnya supervisi dilakukan dalam rangka menjamin pembelajaran yang berkualitas. Artinya, bahwa keberhasilan pelaksanaan supervisi Artinya, bahwa keberhasilan pelaksanaan supervisi diukur dari peningkatan prestasi belajar diukur dari peningkatan prestasi belajar siswa. siswa. (Sabandi, 2013) (penelitian Tenriningsih, 2009) menemukan bahwa "terdapat hubungan langsung yang positif dan signifikan antara kinerja guru dengan prestasi belajar siswa dan terdapat hubungan langsung yang belajar siswa dan terdapat hubungan langsung yang positif dan signifikan antara prestasi belajar siswa positif dan signifikan antara prestasi belajar siswa melalui melalui supervisi pengajaran". Artinya semakin inggi kinerja guru, semakin tinggi prestasi belajar tinggi kinerja guru, semakin tinggi prestasi belajar siswa. Karena itu, untuk menghasilkan kinerja guru siswa. Karena itu, untuk menghasilkan yang tinggi diperlukan supervisi pengajaran yang tinggi diperlukan supervisi pengajaran yang efektif.

Menurut (Lis Yeti Suhayati, 2013) (mengutip Depdikbud, 2004;130) menyatakan bahwa Supervisi Akademik Kepala Sekolah adalah bagian dari supervisi pendidikan (educational supervision) yang langsung berada dalam lingkup kegiatan pembelajaran yang dilakukan oleh guru, sehingga ditujukan untuk meningkatkan mutu proses dan hasil pembelajaran.' Supervisi Akademik Kepala Sekolah adalah bantuan profesional kepada guru, melalui siklus perencanaan yang sistematis, pengamatan yang cermat, dan umpan balik yang obyektif, sehingga dengan cara itu guru dapat menggunakan balikan tersebut untuk memperbaiki kinerja mengajarnya". Oleh sebab itu palaksanaan supervisi yang baik akan berdampak baik terhadap kualitas dari sekolah tersebut. Karakter yang baik dari siswa melambangkan professionalitas dari seorang guru, kemudian kualitas seorang guru melambangkan kualitas seorang kepala sekolah sebagai pemimpin dan supervisor di sekolah tersebut. Pengawasan yang tidak optimal, pengaturan yang tidak baik, kebijakan sekolah yang tidak tepat sasaran secara tidak lansung akan berdampak buruk terhdap siswa. Oleh sebab itu diperlukan pengaturan supervisi yang baik sehingga akan memberikan dampak yang baik terhadap setiap element yang ada di sekolah tersebut.

\section{Kesimpulan}

Berdasarakan uraian di atas disimpulkan bahwa pengaturan supervisi yang baik berdampak baik terhadap element yang ada di sekolah tersebut. Karekter seorang siswa akan dapat terbentuk dengan baik melalui proses 
pembelajaran yang baik dari seorang guru, dan kualitas seorang guru juga dipengaruhi oleh bagaimana kepala sekolah mengatur, membina, dan mengawasi proses pembelajaran.sehingga dengan itu diharapkan pendidikan berkatakter terhadap siswa dapat di wujudkan.

\section{Saran}

Supervisi haruslah di atur dengan dengan baik, benar dan bijaksana oleh yang memiliki kewenangan untuk mengatur. Supervisi tidak cukup hanya sekedar konsep dan teori, butuh pengaplikasian berupa pelaksanaan real di lapangan dan juga perlu pengawasan yang terstruktur dan berkelanjutan.

\section{Referensi}

Citra, Y. (2012). Pelaksanaan Pendidikan Karakter Dalam Pembelanjaran. Jurnal Ilmiah Pendidikan Khusus, 1(1), 237-249. Retrieved from http://ejournal.unp.ac.id/index.php/jupekhu

Ekosiswoyo, R. (2007). Kepemimpinan kepala sekolah yang efektif kunci pencapaian kualitas pendidikan. Jurnal Ilmu Pendidikan, 14(2), 76-82.

Lis Yeti Suhayati. (2013). KINERJA MENGAJAR GURU Oleh : Iis Yeti Suhayati. Jurnal Administrasi Pendidikan, $17(1), 86-95$.

Sabandi, A. (2013). Supervisi Pendidikan Untuk Pengembangan Profesionalitas Guru Berkelanjutan. Jurnal Ilmiah Ilmu Pendidikan, XIII(2), 1-9.

Wardani, K. (2010). Peran Guru Dalam Pendidikan Karakter Ki Hadjar Dewantara. Proceedings of The 4rd International Confrence on Teacher Education; Join Confrence UPI \& UPSI, (November), 230-239. 